\title{
Transposition
}

\section{International Archives and National Music Competitions: The Preservation of an "Endangered" Musical Heritage in the Saharawi Refugee Camps (Southwest Algeria)}

Archives internationales et concours de musique nationale : la préservation d'un patrimoine musical « menacé » dans les camps de réfugiés sahraouis (Algérie du Sud-Ouest)

\section{Violeta Ruano Posada}

\section{(2) OpenEdition} Journals

Electronic version

URL: http://journals.openedition.org/transposition/3513

DOI: $10.4000 /$ transposition.3513

ISSN: 2110-6134

Publisher

CRAL - Centre de recherche sur les arts et le langage

Electronic reference

Violeta Ruano Posada, «International Archives and National Music Competitions: The Preservation of an "Endangered" Musical Heritage in the Saharawi Refugee Camps (Southwest Algeria)»,

Transposition [Online], 8 | 2019, Online since 15 September 2019, connection on 16 December 2020

URL : http://journals.openedition.org/transposition/3513; DOI : https://doi.org/10.4000/transposition. 3513

This text was automatically generated on 16 December 2020 .

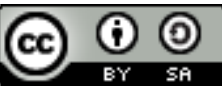

La revue Transposition est mise à disposition selon les termes de la Licence Creative Commons Attribution - Partage dans les Mêmes Conditions 4.0 International. 


\section{International Archives and National Music Competitions: The Preservation of an "Endangered" Musical Heritage in the Saharawi Refugee Camps (Southwest Algeria)}

Archives internationales et concours de musique nationale : la préservation d'un patrimoine musical «menacé » dans les camps de réfugiés sahraouis (Algérie du Sud-Ouest)

Violeta Ruano Posada

In a fast-changing world in which wars, mass displacement and almost daily technological advances are commonplace, the preservation of endangered traditional cultural practices has become a key priority in the policies of many countries and international organisations. This preservation is often linked to the protection of cultural diversity, intercultural dialogue and community attachment, especially against the effects of globalisation and conflict. As discussed by ethnomusicologists and experts in cultural conservation, cultural practices-especially oral traditions-are often perceived as being at risk of disappearing or being diluted when they come into contact with outside influences, or when the socio-political circumstances of the communities who practice them dramatically shift. ${ }^{1}$ This debate, Catherine Grant has argued, ${ }^{2}$ depends in particular on the very definition of the word endangered and the issues around the artificial versus natural evolution of cultures. Thus, in some cases this perception of cultures "at risk" fails to acknowledge the natural changes that have always occurred to all traditions over the ages; in other cases, particularly when tied to issues of contested identity and nationalism, this can create real social and political turmoil. 
2 The UNESCO Lists of Intangible Cultural Heritage established in 2010 are one of the best-known large-scale projects aimed at preserving oral traditions, and a strong example of how national identities and political understandings are at play in efforts to preserve a culture. The two UNESCO lists ${ }^{3}$-the Representative List of the Intangible Cultural Heritage of Humanity and the List of Intangible Cultural Heritage in Need of Urgent Safeguarding-comprise an extensive catalogue of intangible practices that have been chosen as contributors to global cultural diversity and/or in need of safekeeping. The practices are submitted for consideration and categorised on a nationstate basis, ensuring that participating countries can use the UNESCO seal to mobilise the necessary support and international cooperation that ensures, in theory, the transmission of their heritage. Inclusion on these lists, thus, gives both the country and the tradition being supported important international recognition, which also has significant economic, social and political benefits for the state. On the other hand, it is important to acknowledge that participation in these schemes can have equivocal effects on the traditions and their artists, and, in many cases, having UNESCO's support is not enough to safeguard the whole tradition. ${ }^{4}$

3 Moreover, despite the large-scale impact and overall advantages of such a scheme, the way it operates can be problematic, especially for developing countries that lack the infrastructure to submit a successful application. ${ }^{5}$ This is particularly true of longstanding unrecognised states that have little or no chance of accessing cultural recognition from organisations like UNESCO, such as the Saharawi Arab Democratic Republic (SADR), also known as Western Sahara, currently established in the so-called Saharawi refugee camps (southwest Algeria). ${ }^{6}$ The political vulnerability of these selfproclaimed states, often marked by conflict, forced displacement and long-term exile, is extended to their cultural heritage, which is usually subject to integration, appropriation and in some instances disappearance. In these cases, oral traditions become important political weapons in the struggle for self-determination, given their key ability to reinforce national identities. ${ }^{7}$ In turn, their over-politicisation makes these practices even less attractive in terms of gaining the support of international bodies, which are usually wary of being seen as "taking sides" in any international conflict. So what, then, happens to traditions caught in the middle of such confrontations? Are they being preserved and transmitted, and if so how? Is it important that they gain international recognition, and if so, why?

Drawing on ethnographic methods including participant observation, music recording and interviews with musicians at the Saharawi refugee camps between 2012 and 2016, this paper examines these questions focusing on two Saharawi music case studies: 1) the music preservation project Portraits of Saharawi Music (2013-2014), developed by the author with the Saharawi Ministry of Culture and the British Library, and 2) a music competition during the Saharawi national celebrations in February 2014. The article explores the efforts of the Saharawi cultural authorities to safeguard their musical heritage in a situation of extreme vulnerability, mixing material (recorded archives) and non-material (oral transmission) strategies. It also analyses the ways in which socio-political interests such as the reinforcement of an unrecognised national identity have helped to keep particular genres (e.g. traditional/national) alive under the label of intangible heritage preservation. 


\section{The Saharawi case: oral culture, identity and the struggle for self-determination}

5 The Saharawi Arab Democratic Republic (SADR) is one of the longest-standing contested states in the world. It was proclaimed on 27 February 1976 by the Polisario Front, the Saharawi liberation movement that aimed to turn their country Western Sahara-until then a Spanish colony in the Trab el-Bidhân region of northwest Africa ${ }^{8}$ into an independent nation with the support of several decolonisation resolutions that the United Nations had issued since $1964 .{ }^{9}$ A few months earlier, however, Spain had transferred administration of the territory to the neighbouring countries Morocco and Mauritania with the signing of the secret Tripartite Madrid Accords (14 November 1975). This prompted a double invasion of the Saharawi land-with Morocco entering from the north and Mauritania from the south ${ }^{10}$-that led to a sixteen-year-long war (1976-1991) and forced more than half of the local population-over 40,000 people ${ }^{11}$-to flee and become refugees in Algeria. After months of exodus through the desert, the Polisario Front established five refugee camps (wilayas) near the desert city of Tindouf, naming them after five different cities in Western Sahara: Smara, Ausserd, Al Aiun, Dakhla and Boujdour (see fig. 1). ${ }^{12}$ There, in the middle of the harsh Algerian hammada, ${ }^{13}$ they laid the foundations for their own nation-state in exile, building infrastructures such as ministries, administration, schools and hospitals, etc. Each of the five residential refugee camps has its own town hall (wilaya), divided into councils (dawair; sg. daira) and neighbourhoods (lahyay) for administrative purposes.

To date, the Saharawi republic in exile has been recognised by only eighty countries around the world. ${ }^{14}$ The Saharawi refugee population, which now stands at around 200,000 people, has come to embody the national cause, to the point that each person names independence as their ultimate personal goal. Aware of their refugee status, and proud of their willingness to live in the harsh Algerian desert before going back to an occupied Western Sahara, they consider the internationalisation of the struggle, be it through political, social or cultural/musical means, as the main weapon they currently have against Morocco.

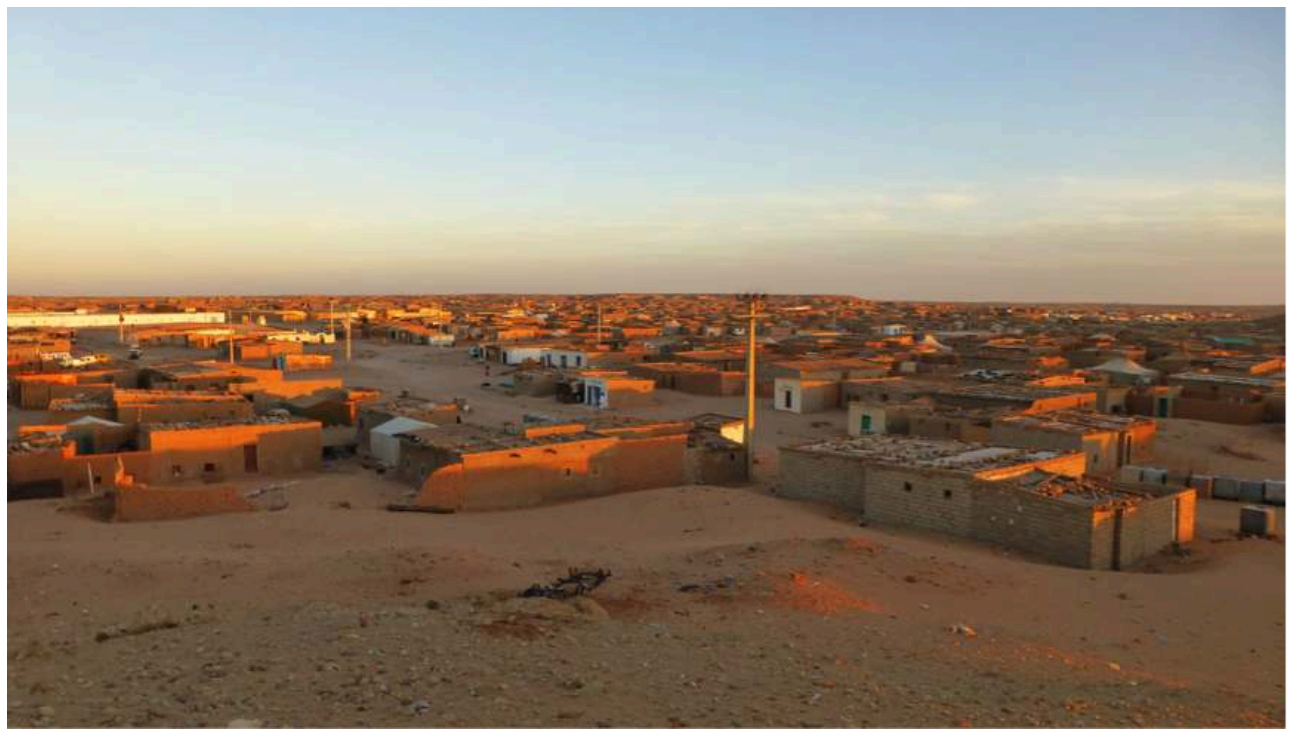

Fig. 1: View of Boujdour camp, by the author 
7 Throughout the past four decades, oral culture-especially music and poetry-has been at the core of the Saharawi struggle for self-determination and their construction of national narratives in exile. In the years leading up to the revolution and during the war, the Polisario leaders encouraged Saharawi poets and musicians to compose and perform tunes that praised the values of the revolution and remembered key historical figures, martyrs and battles. Though new compositions-in a style the Saharawis call elnidal (struggle)-these tunes were based on traditional songs and ballads from the nomadic Bidhân culture, following a trend that was in vogue in West Africa during the first years of independence. ${ }^{15}$ In order to use their cultural traditions to help promote their new state, the Polisario created a Saharawi Ministry of Culture within their nascent government in exile. Throughout the war years, el-nidal was established as the Saharawi national musical style, performed at both official and non-official celebrations, such as weddings, naming days and other social gatherings. In the long term, this has meant that other traditional themes such as love and landscape have declined, with many songs devoted to them disappearing from the collective memory. ${ }^{16}$ This has been a concern for the Saharawis in more recent times, as stated by the late music star Mariem Hassan: "Since we are so invested in our political situation and above all we sing songs of denouncement and resistance, usually more traditional songs are left on the side". ${ }^{17}$

8 At the same time, after the Morocco-Saharawi war ended in 1991 with the signing of a UN-mediated ceasefire, the Moroccan government gradually changed their policies on the occupied territory Western Sahara, shifting from open conflict to the appropriation of Saharawi culture and identity as part of the building of a Moroccan hybrid national identity. ${ }^{18}$ This was done through various means, such as TV channels, websites and academic conferences, as well as mass cultural festivals celebrated regularly in the occupied territories, e.g. the Festival of Hassani Poetry in Dakhla, the Festival International Rawafid Azawane in Al Aaiun and the Boujdour Festival ${ }^{19}$, and in southern Morocco, traditionally Bidhân land, e.g. the Taragalte Festival ${ }^{20}$ in M'Hamid El Ghizlane and the Moussem Festival in Tan Tan. This last festival was included in the UNESCO list of Masterpieces of Oral and Intangible Heritage of Humanity in 2005 as part of Morocco's national cultural heritage. ${ }^{21}$ This kind of cultural appropriation has been strongly rejected by the Saharawi communities living under occupation, who have been exerting their own Saharawinness by performing traditional and even revolutionary music from the refugee camps across the desert, at wedding parties and other social gatherings such as naming days and the reception of visitors. ${ }^{22}$ This situation has created a true cultural war in parallel to the political conflict between Morocco and the Saharawis both in exile and under occupation. ${ }^{23}$

\section{Musical patrimonialisation as a form of resistance}

9 Particularly concerned about the effects of protracted exile and Moroccan appropriation of their cultural heritage, and inspired by international initiatives such as the 2003 UNESCO Convention for the Safeguarding of the Intangible Cultural Heritage, in 2008 the Saharawi Ministry of Culture (see fig. 2) created the International Observatory for the Protection of the Cultural Heritage in the Western Sahara, ${ }^{24}$ a platform aiming to protect Saharawi archaeological, architectonic, natural and oral heritage. Within Saharawi culture, this is the first time that the word heritage-"patrimonio" in 
Spanish (their former colonial language, still commonly used in official contexts)-was used to describe their oral traditions.

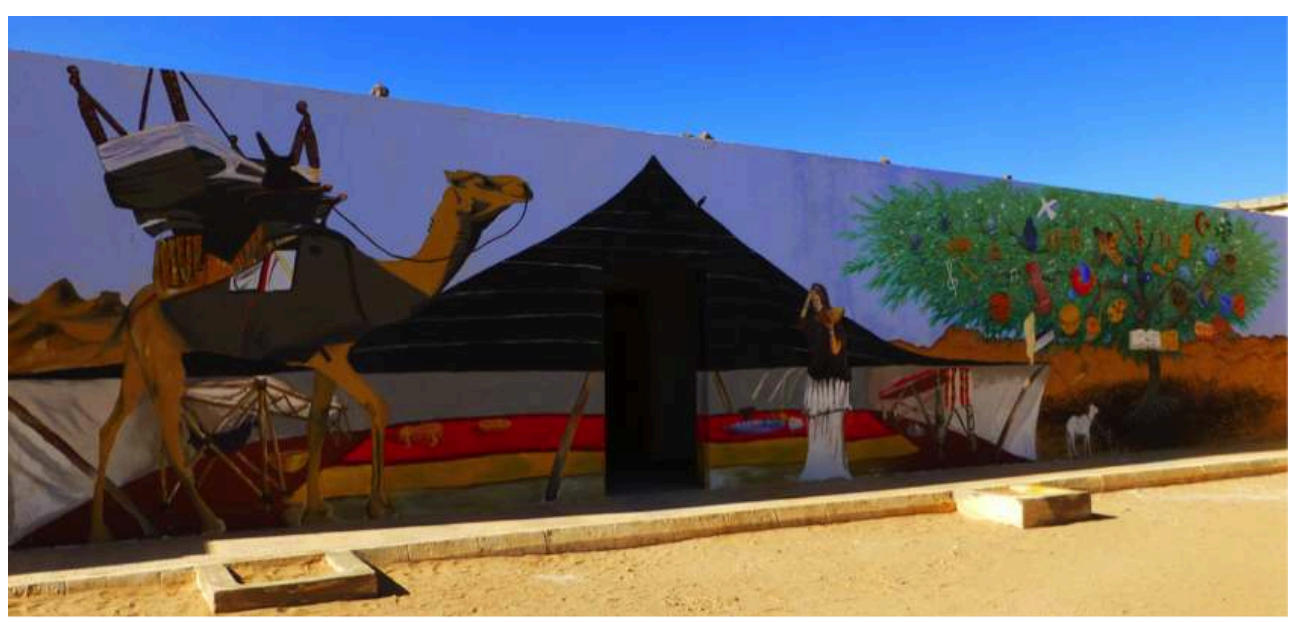

Fig. 2: Front wall of the Saharawi Ministry of Culture's main building, by the author

Since then, the Saharawi government has also put into motion a series of projects to specifically preserve and promote their oral culture, including both traditional and revolutionary poetry and music styles. Such initiatives include: the poetry archival projects ¡Cuéntame, abuelo! and Legna, habla el verso saharaui (2010 and 2014, Autonomous University of Madrid, Spain), which culminated in the release of the film Legna, habla el verso saharaui ${ }^{25}$ the music archival project ¡Cuéntame, abuelo! Música (2012, Music Conservatory of Salamanca, Spain), which culminated in publication of the book Haul. Música Saharaui, ${ }^{26}$ and the collection of Saharawi music albums released in the 1990s and 2000s by the Madrid-based record label Nubenegra. These initiatives have mainly been developed in collaboration with Spanish organisations and universities due to colonial and postcolonial ties between the two countries, which has largely limited the ability of Saharawi culture to reach audiences beyond the Spanish-speaking world. Nevertheless, interest in Saharawi music has broadened in recent years, partly due to the international success of Saharawi singers such as Mariem Hassan and Aziza Brahim, which has translated into the development of projects with organisations outside Spain, e.g. the music empowerment project Studio-Live (2012, London-based charity Sandblast $)^{27}$ and the music preservation project Portraits of Saharawi Music (20132014, British Library).$^{28}$ In addition to the music recording projects, the Saharawi Ministry of Culture also organises large cultural festivals once a year in the Saharawi refugee camps. Aimed at both national and international audiences, the Saharawi authorities uses these festivals to showcase the Saharawi traditional culture and encourage the younger generations to research and perform their own oral traditions by establishing dialogues with the elders.

Through the showcasing and promotion of their nomadic oral culture, ${ }^{29}$ the Saharawi Ministry of Culture seeks to safeguard an intangible cultural heritage that they consider an important part of humanity's patrimony. At the same time, they are also actively encouraging the Saharawi people to perform their nation ${ }^{30}$ and promote their independent identity-as distinctly as possible with regard to Moroccan national identity-through any possible cultural means, and especially through music. Thus, the Saharawi case offers a strong example of how the preservation of heritage can be inextricably linked to politics and a form of resistance. So far, however, even though 
these measures have had a significant short-term impact on the local population, as examined through the case studies presented below, it has proven difficult to sustain them in the long term and to achieve the wider recognition that would propel the Saharawi cultural struggle into the international arena.

\section{Portraits of Saharawi Music: the archiving of an oral culture}

12 The music preservation project Portraits of Saharawi Music was developed in the Saharawi refugee camps during 2013 and 2014 as a collaboration between the Saharawi Ministry of Culture and the British Library, with myself acting as project manager, mediator and head researcher. The project had three main objectives, each corresponding to one of the partners' aims:

13 1) To create the first collection of field recordings of Saharawi music to be deposited in the British Library archive, contributing to oral heritage preservation initiatives in the camps. This dual objective was established by the World and Traditional Music Department of the British Library at the outset: on the one hand, seeking to increase their collection of music recordings from around the world, while, on the other hand, also complementing local efforts. In this second aim, part of the agreement was for high-quality copies of all recordings to be left in local institutions, such as the local Music School, the National Library and the National Archive, which are open to the general public.

14 2) To build a platform for Saharawi culture in the English-speaking world, particularly to encourage further academic research, a goal established by the Saharawi Ministry of Culture. As mentioned earlier, the majority of academic-based projects in the camps are led by Spanish institutions, which limits the reach of the research. With the conviction that academic research can be an important way to validate the existence of their independent identity, the Saharawi authorities are interested in creating cultural links with other countries.

15 3) To answer the question "What constitutes Saharawi music according to local standards?" as part of my own doctoral research and as a basis for an article to be published on the British Library's music blog, ${ }^{31}$ thus complementing the previous two objectives. This aim was also paired with special permission given to me by the Saharawi Ministry of Culture to use all findings and recordings in any future not-forprofit academic contexts.

16 In order to develop this project, which was part of my own doctoral research on Saharawi music, I lived for six months in the Saharawi refugee camp of Boujdour with a local family. Saharawi refugee families live in mud huts scattered throughout the camps, along main roads and smaller paths that create intricate patterns, and usually organised according to family groups. Daily life in the harsh Algerian hammada can be very challenging, with extreme temperatures of up to $50^{\circ} \mathrm{C}$ in the summer and below zero on winter nights, frequent sandstorms, unreliability of transport, shortage of water and electricity supplies, and chronic lack of forms of entertainment beyond television and, more recently, smartphones. The local population regularly suffer from stomach illness, skin irritations, congestion of the nose and throat due to the dust, and other diseases related to a forced indoor, sedentary lifestyle, such as diabetes. 
Nevertheless, resilience, determination, hospitality and general good mood are certainly outstanding traits shared by most members of the refugee community.

On a practical level, each the "Portraits of Saharawi Music" partners had its own responsibilities. First, the British Library was the main funder, and provided all the recording equipment, as well as a model agreement and consent forms. Second, the Saharawi Ministry of Culture provided me with access to the different camps, the local directions to cultural centres and participating musicians' homes, as well as a representative-traditional music expert Zaim Alal-in charge of selecting the participating musicians and putting them in contact with the research team. The selection process was based on the availability of the musicians belonging to the official local bands, who were offered the option of voluntarily taking part in the project, or not. In addition, I also approached a handful of artists that were independent from the Ministry, and whom I had previously met through research. It is important to note that the number of active musicians in the Saharawi refugee camps is currently quite limited, which means that we could not be too selective since many had other commitments, even outside the camps. The Ministry's involvement also included overseeing fair payments when requested by musicians. We soon learned, however, that musicians who saw their participation in the project as activism for their national struggle, usually the older musicians, were reluctant to accept any compensation for their music. On the contrary, those who were pursuing a professional career in music, mostly artists who had not lived through the war, did expect payment. This matter is also linked to existing taboos about money and the arts-and, in fact, money in general -within the Saharawi society. ${ }^{32}$

Finally, I had a multifaceted role as mediator between the two institutions, also acting as project manager and lead researcher in charge of designing the sessions, recording the music, planning and conducting the interviews, collecting all the materials, overseeing the translation team (formed by translator Umetha Hamdi and myself), and creating opportunities for musical and cultural debate among the musicians and other cultural figures. I was also responsible for providing copies of all the materials to the three local institutions mentioned above, and ensuring that the project got as much public exposure as possible, mainly through online and traditional media, in order to promote Saharawi music and independent identity. It is worth noting that this multifaceted role raised several ethical questions regarding both my position towards my local collaborators-especially since I was not only managing this project, but also researching for my $\mathrm{PhD}$ thesis-and my own academic integrity. How could I develop a project to advance the Saharawi political claims and, at the same time, do a constructive and critical analysis of their musical situation? Was it possible to be a cultural rights activist without sounding propagandistic? As Stave Feld stated in his contribution to the book Music Grooves in 1994, "[T] he politics of being an engaged and responsible researcher are now bound up with giving voice to people whose validity, indeed, whose humanity, is denied or silenced by the world's dominant cultures". ${ }^{33}$ Thus, did I have enough moral authority to determine whether or not the Saharawi needed a/my voice? During fieldwork, I learned that answers to these questions were often ambivalent and contradictory, and that I had to constantly reassess the multiple identities I was assuming while interacting with the Saharawis in an "intimate, longterm and multi-stranded way". ${ }^{34}$ 

five Saharawi refugee camps-Boujdour, Smara, Ausserd, Al Aaiun and Dakhlarecorded over the course of twenty-five different sessions. Throughout a period of six months between 2013 and 2014, the research team-main researcher, translator and the cultural representative-travelled periodically to each camp from our base in Boujdour camp, met with the selected musicians to record their music and interview them in their local language, Hassâniya, and transcribed and translated all the material (lyrics and interviews) into English and Spanish in order for the project to have a larger impact. Participating musicians were from different generations and performed diverse musical styles, therefore offering different opinions on what Saharawi music means for the Saharawis. As a way to get to know these opinions, the research team did not establish any a priori stylistic rules for the performances; participants were simply requested to play songs that were, in their opinion, representative of Saharawi identity. Later on we found out that the Ministry's cultural representative often added the word "national" to identity when explaining things to the participants. What I initially saw as a way of co-opting musicians into performing nationalistic tunes, and therefore showing their support-and the project's support-for the national cause, ended up also providing interesting insights as to what the labels national, traditional or modern meant to the musicians, especially through the debates they had among themselves when choosing their repertoires or discussing their musical styles. For example, during a recording session in Ausserd camp with traditional singer Mariem Mouloud, one of her accompanists, a guitar player named Abderrahman Mohamed, criticised her for playing a song about a water well somewhere in the desert, considering that it had little to do with their current claims. The singer, without losing her temper, answered back that she was a Saharawi, and that the land and way of life she sang about were, according to her, at the core of their identity as free and independent desert-roamers. Even if her songs did not mention the war, the struggle, or life in exile, they served to remember a time in the past in which the Saharawis were already independent, thus contributing to the "imagi-nation" 35 of the Saharawi republic in exile.

All this work resulted in an eclectic collection of recordings that show the diversity still existing within the Saharawi oral heritage, although they also bring to the fore issues about cultural self-representation within highly politically-charged situations. The recordings can be classified into two categories: 1) modern (el-asri) songs about different aspects of the struggle (nidal); and 2) traditional (tagledi) tunes about love (ghâzal), warriors (ghazzi), spiritual praise in honour of Prophet Mohammed (medeh), and the Saharawi landscape (adlal), proving that even though the war may have forced many traditional songs out of the collective memory, many others are still engrained in that memory, actually reinforcing the Saharawi claim of an independent identity. Interestingly, however, no modern songs about personal or social issues were recorded. When asked about this, both musicians and cultural experts reinstated the idea that their music reflected what the local audiences wanted to hear, and that even though traditional songs about those issues might showcase the richness of their cultural identity, contemporary composers and poets do not have the luxury of being able to focus on anything but their political struggle. The question of whether this is a conscious choice or one that is mainly influenced by the undergoing socio-political situation of the Saharawi community remains unanswered. ${ }^{36}$ 
The traditional/modern dichotomy was also seen in the instruments used, which were both traditional-the voice (male and female) and the tbal drum (played by women)and modern-melodic instruments such as guitars and keyboards (played by men). In addition, due to a chronic lack of resources in the camps that means instruments are scarce and in poor condition, percussionists such as Tarba Bueibu and Habuza in Al Aaiun or Fatma Mohamed in Smara often used other ad hoc objects as drums, such as plastic buckets, metal plates and even the floor (see figs. 3, 4, and 5).

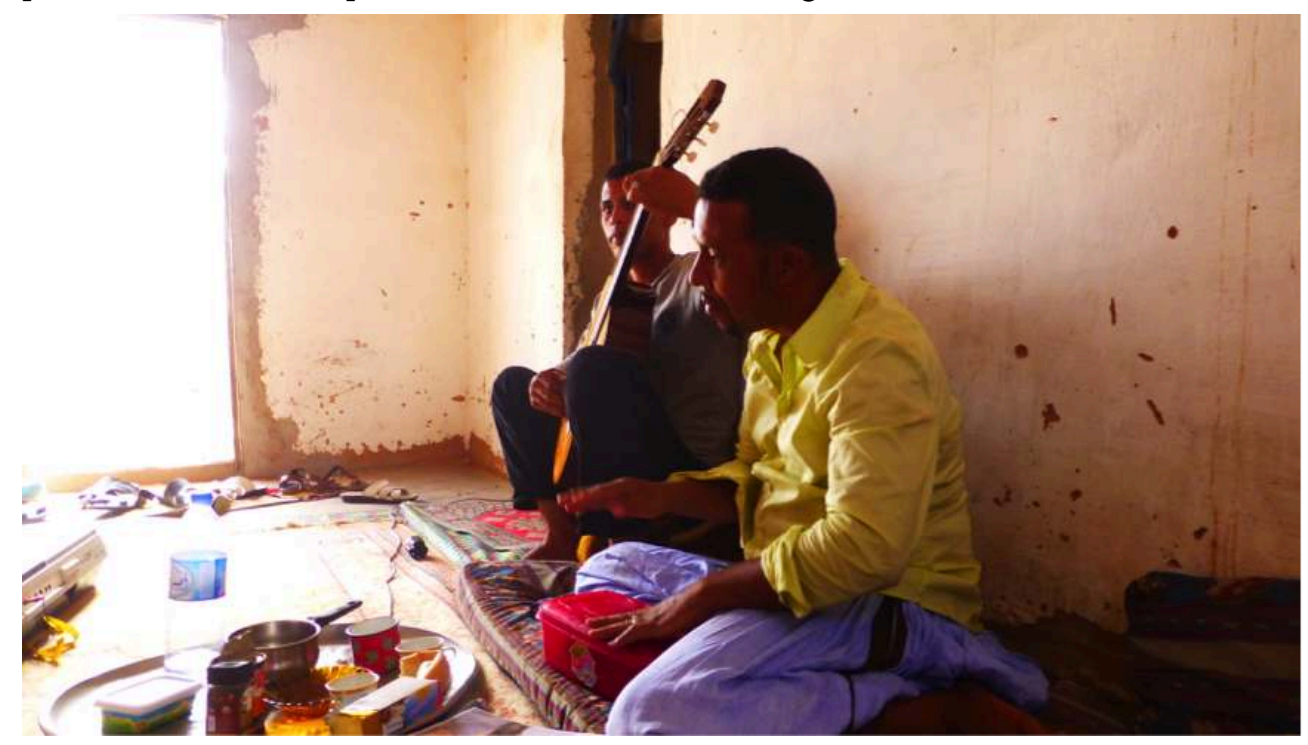

Fig. 3: Participants of Portraits of Saharawi Music project in their house in Boujdour camp, by the author

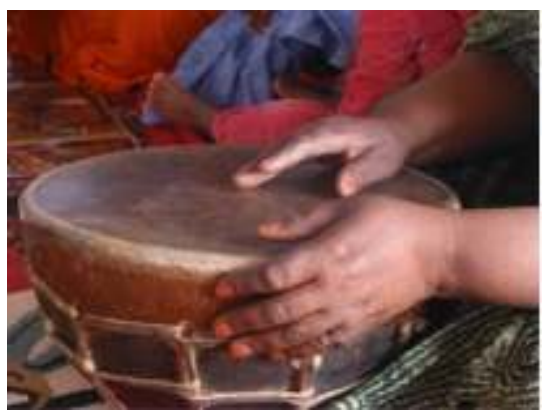

Fig. 4: The Saharawi tbal drum, by the author

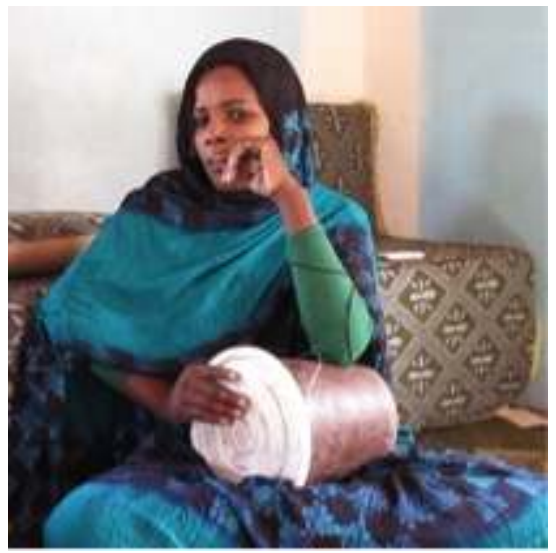

Fig. 5: Percussionist Tarba Bueibu playing a plastic bucket in her house in Al Aiun camp, by the author 

their current situation of conflict and exile, the use of daily objects as drums has in fact been a common feature of Saharawi and Mauritanian nomadic communities, whose desert lifestyle has always been very austere, with limited access to instruments, especially before they became settled in towns such as Nouakchott (Mauritania) and Al Aaiun (Western Sahara) towards the end of the colonial era. ${ }^{37}$ This has been described, for example, by French ethnomusicologist Michel Guignard, who said in 1975 that the Bidhân Moors sometimes accompany human voices with "the soundboard of other instruments or an ad hoc object", ${ }^{38}$ and by French traveller Odette du Puigaudeu, who documented this peculiarity during her trips through Mauritania in the mid- $20^{\text {th }}$ century:

Someone asked Salek to sing. Lounging on the mat, chest raised on his elbow, head turned toward the sky, he sang the religious kar, the fâghu of warriors, and love poems, while gently playing the rhythm with his fingertips on the sugar box... ${ }^{39}$

Therefore, it can be argued that while the experience of refugee life may, in some cases, have forced the disappearance of Saharawi oral traditions, in others it is precisely what has allowed certain aspects of those traditions to survive, and even be revived, showing the resilience and uniqueness of the Saharawi desert identity.

The great majority of the material collected by Portraits of Saharawi Music can now be freely accessed online through the British Library Sounds website. ${ }^{40}$ This platform, which catalogues music by genre, instrument, place of recording and participating musicians, serves not only as a physical repository for the recordings and all the information gathered about them, but also as a way to give visibility to the collection and the culture it represents. In addition, the fact that the recordings can be accessed remotely (although not downloaded without permission) has also been crucial for expanding the project's impact, at both national and international levels. Two examples of this are: 1) the use of the song "Before the union nobody knew the Saharawi", sung by Lmarabet Mahfud Aliyen for the collection, as the basis for a video documenting the Saharawi youth movement "Platform of Cries Against the Moroccan Wall", edited by Saharawi youth group SAHARAWI VOICE; ${ }^{41}$ and 2) the use of the song "Saharawi Revolution", sung by Tarba Bueibu, as part of the British Library CD compilation West Africa at the British Library, distributed exclusively with the December 2015 issue of Songlines magazine (\#113). ${ }^{42}$ Thus, it is through this platform that the first two objectives of the project were fulfilled..$^{43}$

Portraits of Saharawi Music was created and shaped as part of a growing international solidarity and empowerment movement that currently determines the nature of many small-scale collaborative projects between individual foreigners or small collectives and the Saharawi refugees. These projects, while embedded in a heavily politicised and unstable context of protracted conflict and exile, advocate for the reinforcement of existing initiatives in the camps and for the establishment of long-term relationships with local participants in order to encourage their sustainability. In addition, the very nature of the project led all those involved, including myself, to anticipate that both the recordings and my findings would be used to raise awareness about the Saharawi cause for self-determination, thus categorically denying Morocco's claims over Saharawi land and identity. Throughout my research both as part of Portraits of Saharawi Music but also independently, I consistently found that this point was a condition sine qua non for all initiatives developed in the camps, and was accepted and 
reinforced by the local population. Regardless of internal social problems happening within the camps, there is total agreement that Morocco's occupation is both real and unacceptable, a statement that is backed up by over 54 years of UN resolutions, none of which acknowledge Morocco's right over the territory. ${ }^{44}$

It is important to remember that one of Morocco's longest-standing strategies of occupation has been to deny the existence of a Saharawi cultural identity distinct from Moroccan identity, and to use any internal discord among the Saharawis to prove that they are not really a unified voice of protest. It turned out that the recordings in Portraits of Saharawi Music do show a wide variety of musical styles, voices and identities present within the Saharawi refugee society, and not a clearly unified voice of protest. Nonetheless, be it through the remembrance of tradition, the explicit expression of nationalistic claims, or a more subtle use of nomadic musical practices, what makes these voices a unified "heritage" is precisely the fact that they are all an essential part of what it means to be Saharawi, an identity that is currently facing significant challenges.

\section{Who is the most traditional? A music competition in a Saharawi national festival}

27 In addition to archival projects, the Saharawi Ministry of Culture conducts other initiatives aimed at preserving, and especially transmitting, their oral culture. Throughout the year, they organise several traditional arts and cultural festivals in each wilaya, both to showcase different aspects of Saharawi nomadic and revolutionary life, and through the participation of artists across multiple generations, to engage in conversations with the youth. Through these festivals, the cultural authorities seek to provide spaces for debate and the transmission of knowledge in a traditional way-that is, orally rather than through formal education. These events are usually celebrated on an important national holiday-such as February $27^{\text {th }}$ (founding of the Saharawi republic), May $20^{\text {th }}$ (founding of the Polisario Front), or October $12^{\text {th }}$ (the Saharawi National Union Day)-making a strong link between the celebration of cultural life with the "imagi-nation" 45 of the Saharawi republic in exile. Some of these festivals also coincide with the hosting of an international event organised in collaboration with a foreign organisation, e.g. the sports event Sahara Marathon every February (coordinated with the Ministry of Youth and Sport), the film festival FiSahara, usually every May, or the arts festival ArTifariti every October.

On 27 February 2014, I attended the festival in celebration of the Saharawi national holiday in the wilaya of Boujdour. As is common in Saharawi cultural festivals, the event was divided into three major episodes: 1) a parade showcasing Saharawi traditions, from fishing to dancing; 2) a series of black tents in imitation of the old nomadic camps, featuring different Saharawi traditional arts and including a music competition; and 3) a final concert that involved singing, dancing, the reading of revolutionary poems, and political speeches. In the following section, I describe the music competition as a way of illustrating the Saharawis' efforts to perpetuate the transmission of their culture.

There were around sixteen traditional black khyam (tents) at the back of the festival arena standing in an almost perfect line, in imitation of a nomadic frig (camp). ${ }^{46}$ Each of 
the tents was dedicated to a traditional activity (cooking, herbal medicines, sand board games, performances, etc.). In one, I could see a group of around thirty young women in traditional black and white clothes (colours usually reserved for weddings and spiritual music performances), chatting enthusiastically. Their multicolour and golden hair ornaments made an incessant clicking noise every time they moved their heads; in the air, there was a poignant smell of perfume and incense. In the khayma there were also a few other people observing them, including a group of small children. All girls were from the regional cultural group of the Boujdour's daira (council) of Agdi. They were sitting in a large semicircle, and a big tbal drum was being passed from hand to hand, each of the girls having a go at it with a few taps. Finally, the drum arrived at the middle of the semicircle and was picked up by an older woman who seemed to be leading the group. She was Faknash Abeid, a traditional singer and drummer I had met during my research in the wilaya of Smara. The moment I recognised her, I realised that the khayma I was in was about to become the stage for the representation of a medeh (spiritual music) performance.

Faknash started casually tapping the tbal, slowly forming a clear rhythmic pattern that the rest of the group started to imitate by handclapping. The loud chattering did not stop. Suddenly, two people jumped from the crowd and started dancing in front of the performers. At first, I thought they were two young men, since they were wearing male robes (drari'), and their faces were completely covered with a turban (lizem). However, I then realised they were two girls that had put on male clothes over their own female dresses (mlâhef, sg. melhfa); their big sunglasses and shiny platform shoes had given them away (cf. fig. 6). Looking around, I could see other girls in drari'. In the Saharawi refugee camps, women dressing as men is not uncommon, especially in militarised contexts where it is a sign of female emancipation. A few minutes later, the group started performing the medeh tune "El haramein" ("The two holy mosques"), led by Faknash with the girls handclapping and repeating the chorus. One of them started dancing, this time fully dressed as a woman, barefoot and with her head and face completely covered by the upper part of her melhfa; soon, others followed.

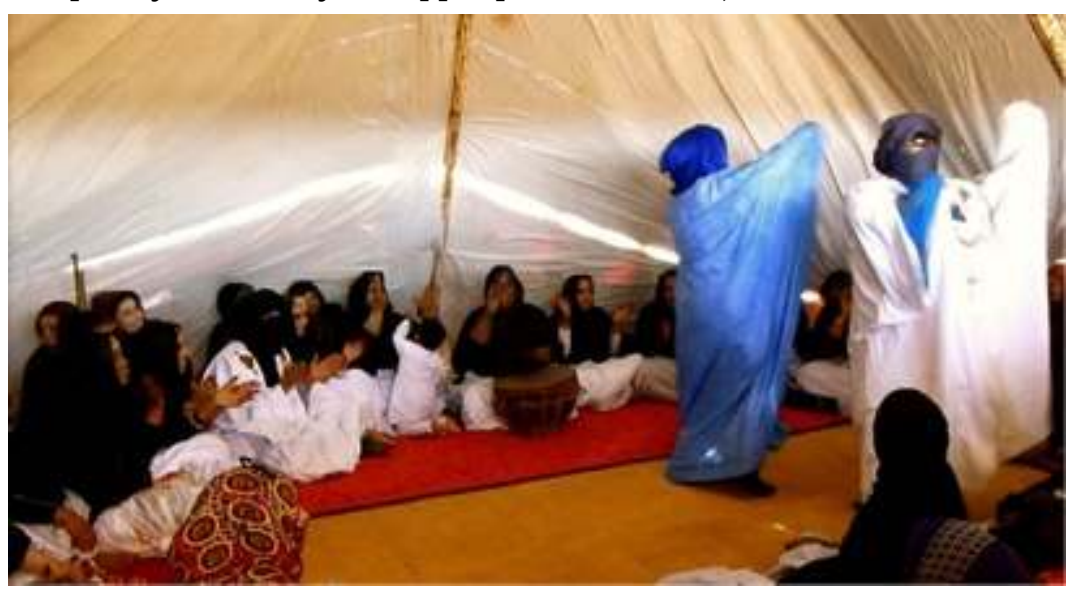

Fig. 6: Two girls dancing in male clothes, by the author

31 I found a similar scene in the next tent, where another group of women and a few men had gathered to perform and dance to traditional music. This time, they were accompanied by the sound of an electric guitar playing a traditional instrumental dance tune used as accompaniment for epics and war stories, and that celebrates victory in war: the sharaa or charha. ${ }^{47}$ This repetitive guitar riff was accompanied by a 
drum machine and the assertive sound of a large tbal, played by a smiling woman who was combining her drumming with handclapping. Other women were also sitting around and handclapping, occasionally getting up to dance for a few minutes, representing the celebration of a battle. After enquiring with some members of the audience, who were cheerfully encouraging the dancers, I learnt that all these women belonged to the cultural office of Boujdour's daira of Lemsid. The local cultural authorities had set up this one-day music competition between Boujdour's three dawair -Agdi, Lemsid and $27^{\text {th }}$ February ${ }^{48}$-in order to see which one could give the most traditional performance. There were no other guidelines; everybody was supposed to know what "traditional" meant. The judges were hidden among the members of the audience, and their role was to observe the performances, the participants' clothing and the decoration of the khyam throughout the whole day. Through more enquires, I also learnt that youngest participants had spent a few weeks gathering information on traditional nomadic life from their elders to be able to represent it as accurately as possible at the festival.

In the next tent I came across the performance put together by the third daira, $27^{\text {th }}$ February. It was the representation of a traditional wedding party. Singer Maddi Lehbib, who also works for the Ministry of Culture and usually performs at national events, was leading the wedding celebrations. Under his supervision, a group of young boys and girls in bright traditional clothes were performing a variety of court dances in pairs, to the sound of a keyboard and a drum. Most dancers were associated with the Boujdour branch of the UJSARIO, the Saharawi National Youth Union. This connection was representative of the nationalistic spirit that had been imprinted on the whole festival.

One of the couples, formed by Hareira and Salem, two activist members of the Youth Union, drew particular attention from the audience, who cheered and handclapped enthusiastically throughout their performance, despite the performers' constant giggling. They were both amateur dancers, which in a way fit perfectly with the family atmosphere of traditional Saharawi weddings (see fig. 7). In the general excitement, Maddi set down his microphone, got up and, to the amazement of the audience, started showering the couple with money. His action-clearly symbolic since the musicians gave back the money at the end-somehow had interesting social connotations. Giving money to musicians and dancers to show appreciation during their performances is extremely rare in the refugee camps, even though it is widespread among professional musicians in other parts of the Bidhân region. The relationship between musicians and money, particularly in the context of weddings and other non-governmental contexts, is always problematic in the Saharawi refugee camps. Most artists, as mentioned earlier, strongly argue that Saharawi musicians have never performed for money, and thus tipping them for their performance could even be seen as an offence. In addition, while generosity is a strong social value in the camps, flashing one's wealth in front of others is considered to be in poor taste. After all, everybody in the camps is still a refugee, regardless of their wealth. Nowadays, wedding musicians usually charge a prearranged fee to the family organising the event; tipping, however, remains rare. 


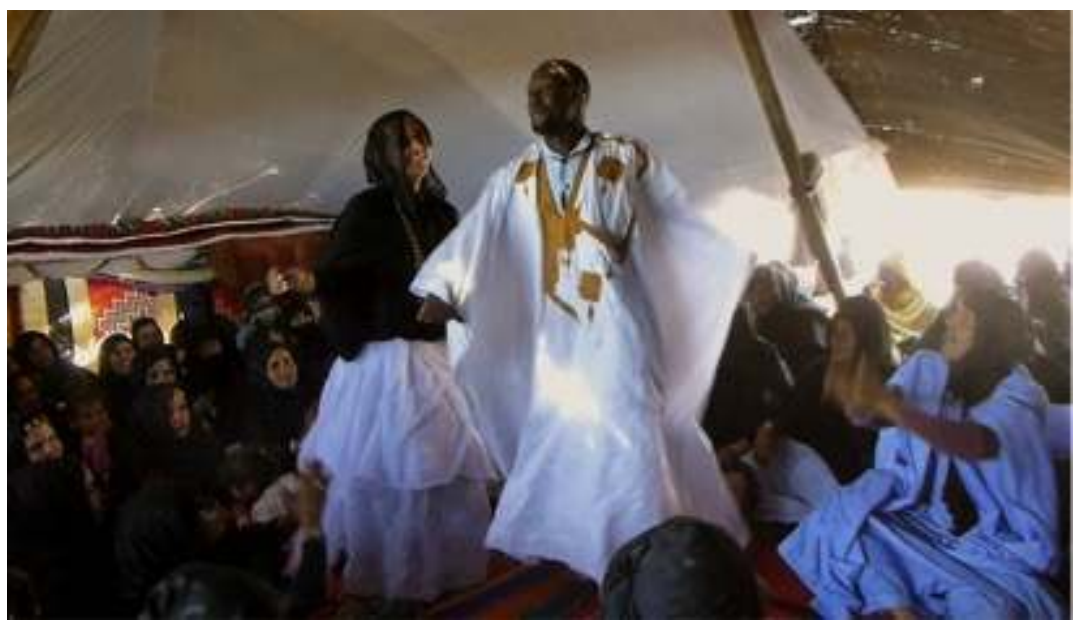

Fig. 7: Hareira and Salem performing a wedding dance, by the author young couple with money as a representation of traditional Saharawi culture during the most important Saharawi national celebration. In her reflection on the politics of tipping during taarab performances in Tanzania, Askew observed that "tipping provides people with the means of appropriating" the meaning of the music, calling it "the audience's medium of participation". ${ }^{99}$ This appropriation is an important part of the performance, where symbolic meanings are negotiated. Following this argument, Maddi's performance of tipping-which in another context could be offensive-can be understood as an appropriation of a tradition currently foreign to his own culture as a way to negotiate his participation in the festival. In a way, through this act Maddi was consciously performing three different roles: lead singer, or voice, wealthy patron and, finally, national master of ceremonies. performance of a victorious war sharaa dance had been chosen as the most "traditional". The young contestants were disappointed because they thought that they had been the most original performers and deserved public recognition. I enquired about the meaning of originality in the context of a traditional performance. Was not the representation supposed to be as close to the tradition as possible? Was not that, in fact, the only guideline? How does innovation and originality fit into the traditional Saharawi narrative? Their answer was clear: people had cheered constantly throughout their khayma; it had been the most successful from the audience's point of view, and therefore they should be the winners. To them, faithfulness to tradition was secondary.

This discussion linked to the close examination of the different aspects of the competition highlights a series of concerns regarding what was being showcased and transmitted through the performances, challenging binary categorisations such as tradition/revolution, male/female, old/young, professional/amateur, and state/society within Saharawi culture. The winning tent, Lemsid, had offered, according to the judges, the most traditional performance. From an audience point of view, it was also the most revolutionary, since they were dancing to the sound of a war melody. This group was, in addition, the only one of the three that was formed of mature women; both Agdi and $27^{\text {th }}$ February, despite being led by two professional musicians, Faknash Abeid and Maddi Lehbib, were composed of young and inexperienced participants. In their search for an authenticated performance, the young women from Agdi had 
resorted to cross-dressing in order to also represent male dancing, re-enacting the revolutionary ideology of female emancipation, which is at the core of the theoretical grounding of the Saharawi state. However, in a traditional setting, a group made up only of women could have presented an all-female performance, especially in a medeh context.

The $27^{\text {th }}$ February participants felt that although performing a traditional wedding had led them to do research and learn about their traditions-currently one of the top aims of the Saharawi Ministry of Culture-the audience's recognition should have played a bigger role in the judges' decision. It is important to note that, within traditional Bidhân musical culture, audience recognition is a key element in judging musicians' talent, something that the cultural authorities had also tried to incorporate by hiding the judges among the members of the audience. Decisions about the faithfulness to and value of traditional practices-and their most recent performances-were thus contested, sparking key negotiations between the performers, their audiences and the cultural authorities about the kind of cultural traditions and values that were to be orally preserved and transmitted through the competition, and by what means.

\section{Conclusion: the preservation of an endangered musical heritage in exile} have been blossoming and dying away through history. Yet if it is 'in their nature' for cultural traditions to disappear (Christensen 1992: 108), a strain seems to exist between artificially keeping them alive and permitting them to be subject to natural evolutionary processes" ${ }^{50}$ This statement suggests that any external efforts to tamper with the natural evolution of musical repertoires does more harm than good for the self-regulation of cultural ecosystems. However, Grant continued, "Over the past few decades in particular, human agency itself has substantially disrupted the natural order of evolution and survival of cultures and cultural heritage". ${ }^{51}$

The recent Saharawi history of conflict and protracted exile, which has provoked scarcity and extreme dependency on outside providers for the refugee population, has severely-and artificially-affected the survival of their musical heritage. Nevertheless, despite their refugee status, the international lack of recognition of their nation-state, and their continuous lack of resources, for the past four decades the Saharawis have succeeded in organising their own government in exile. This government, aided primarily by international collaborations, has put special emphasis on the creation and development of their Ministry of Culture. This is due to Saharawis' understanding of culture, and particularly their oral culture, as one of the most important signifiers of their contested independent identity, and thus, worth being safeguarded, recognised internationally, and transmitted to the younger generations. Interestingly, in spite of their inability to access international preservation programmes such as the UNESCO lists, the Sawaharis have pursued preservation in similar ways, using both material (archives) and non-material methods (oral transmission through the encouragement of intergenerational musical dialogue).

This situation has also led to continuous politicisation of these initiatives-which are primarily seen as ways to reinforce the Saharawi national identity-and

Transposition, 8 | 2019 
encouragement to safekeep particular music styles, such as nationalistic songs describing various aspects of their recent history of conflict, or tunes from the prerevolutionary repertoire that remember or imagine a past in which the Saharawis were free and independent. As has been explored through the examples of Portraits of Saharawi Music and the music competition of the National Cultural Festival on 27 February 2014, preserving Saharawi music culture and its transmission to the next generations is not just a matter of keeping the Saharawi intangible cultural heritage alive; first and foremost, it is a key element in their their struggle, a means of ensuring the very existence of their community and the identity they represent.

\section{BIBLIOGRAPHY}

ASKEW Kelly, Performing the Nation: Swahili Music and Cultural Politics in Tanzania, Chicago, University of Chicago Press, 2002.

BÁRBUlo Tomás, La Historia Prohibida del Sáhara Español. Las Claves del Conflicto que Condiciona las Relaciones entre España y el Magreb, $2^{\text {nd }}$ ed, Madrid, Destino, 2010.

BOUKHARS Anouar and ROUSSELIER Jacques, Perspectives on Western Sahara: Myths, Nationalisms, and Geopolitics, Lanham, Rowman \& Littlefield, 2014.

BOUM Aomar. "Dancing for the Moroccan State: Ethnic Folk Dances and the Production of National Hybridity”, BOUDRAA Nabil and KRAUSE Josephy, North African Mosaic: A Cultural Reappraisal of Ethnic and Religious Minorities, Newcastle, Cambridge Scholars Publishing, 2007, p. 214-237.

CARO BAROJA Julio, Estudios Sahararianos, Madrid, Calamar, 2008, p. 258.

COUNSEL Graeme, Mande Popular Music and Cultural Policies in West Africa: Griots and Government Policy since Independence, Saabrucken, VDM Verlag, 2009.

DAVIES Charlotte Aull, Reflexive Ethnography: A Guide to Researching Selves and Others, London and New York, Routledge, 2008.

DEUBel Tara Flynn, Between Homeland and Exile: Poetry, Memory, and Identity in Sahrawi Communities, PhD thesis, USA, University of Arizona, School of Anthropology, 2010.

DEUBEL Tara, "Poetics of Diaspora: Sahrawi Poets and Postcolonial Transformations of a TransSaharan Genre in Northwest Africa", The Journal of North African Studies, vol. 17, no.2, 2012, p. 295-314.

DU PUIGAUDEAU Odette et sÉNONES Marion, Mémoire du Pays Maure: 1934-1960, Paris, Ibis, 2000.

FELD Steven, "From Schizophonia to Schismogenesis: On the Discourses and Commodification Practices of 'World Music' and 'World Beat"', KEY Charles and FELD Steven, Music Grooves: Essays and Dialogues, Chicago, University of Chicago Press, 1994, p. 257-289.

GIMÉNEZ AMORós Luis, Haul Music: Transnationalism and Musical Performance in the Saharaui Refugee Camps of Tindouf, Algeria, MMus dissertation, Grahamstown, Rhodes University, 2012. 
GRANT Catherine, "Rethinking Safeguarding: Objections and Responses to Protecting and Promoting Endangered Musical Heritage", Ethnomusicology Forum, vol. 21, no. 1, 2012, p. 31-51. GUIGNARD Michel, Musique, honneur et plaisir au Sahara: étude psycho-sociologique et musicologique de la société maure, Paris, Librairie Orientaliste Paul Geuthner, 2005.

HANDLER Richard, Nationalism and the Politics of Culture in Quebec, Madison, University of Wisconsin Press, 1988.

HARRISON Klisala, MACKINLAY Elizabeth and PETTAN Svanibor (eds.), Applied Ethnomusicology: Historical and Contemporary Approaches, Newcastle Upon Tyne, Cambridge Scholars, 2010.

LASUEN Ainhoa, “Mariem Hassan. 'Nunca hubiera pensado que la música saharaui llegara tan

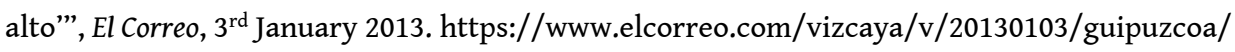
mariem-hassan-nunca-hubiese-20130103.html (accessed on 19 May 2019).

LIPSITZ George, Dangerous Crossroads: Popular Music, Postmodernism and the Poetics of Place, London, Verso, 1997.

MAUREL Chloé, “Whose World Heritage? The problem with UNESCO's famous list”, Equal Times, 20 July 2017. URL: https://www.equaltimes.org/whose-world-heritage-the-problem? lang=en\#.WyRBTlOFPMI (accessed on 24 June 2018).

RUANO POSADA Violeta and SOlANA MORENO Vivian, “The Strategy of Style: Music, Struggle, and the Aesthetics of Saharawi Nationalism in Exile", Transmodernity: Journal of Peripheral Cultural Production of the Luso-Hispanic World, 2015.

RUANO POSADA Violeta, "La musique nidal sahraouie et la lutte en partage", BOULAY Sebastién and CORREALE Francesco, Sahara occidental: conflit oublié, population en mouvement, Tours, Presses Universitaires François Rabelais, 2018.

RUANO POSADA Violeta, "Performing the Cause: The Politics of Musical Expression in the Saharawi Refugee Camps", BOULAY Sebastién and FREIRE Francisco, Culture and Politics in the West Sahara (Mauritania, Mali, Western Sahara): Arts, Activism and the State in a Conflict Area, France, L'Étrave, 2017, p. 101-126.

RUANO POSADA Violeta, "Portraits of Saharawi Music: When Cultural Preservation Meets Political Activism", African Music, Journal of the International Library of African Music, vol. 10, no. 2, 2016, p. 108-125.

RUANO POSADA Violeta, "Shaheed El Uali and Beyond: 40 Years of Resistance Music in Western Sahara", Bring the Noise: Ethnomusicology Review, 26 February 2016.

RUANO POSADA Violeta, “Telling (Hi)Stories through Music: The Power of Performance in the Saharawi Struggle", CARL Florian, FUHR Michael, OTCHERE Eric D. and vOGELS Raimund, Memory, Power, and Knowledge in African Music and Beyond, Germany, Olms-Verlag, University of Hildesheim Press, forthcoming (2019).

STOKES Martin, Ethnicity, Identity and Music: The Musical Construction of Place, Oxford, Berg, 1994. ZUNES Stephen and MUNDY Jacob, Western Sahara: War, Nationalism and Conflict Irresolution, New York, Syracuse University Press, 2010. 


\section{NOTES}

1. HARRISON Klisala, MACKINLAY Elizabeth and PETTAN Svanibor (eds.), Applied Ethnomusicology: Historical and Contemporary Approaches, Newcastle Upon Tyne, Cambridge Scholars, 2010; GRANT Catherine, "Rethinking Safeguarding: Objections and Responses to Protecting and Promoting Endangered Musical Heritage», Ethnomusicology Forum, vol. 21, no. 1, 2012, p. 31-51.

2. GRANT, "Rethinking Safeguarding".

3. ich.unesco.org/en/lists (accessed June 24, 2018).

4. MAUREL Chloé, “Whose World Heritage? The problem with UNESCO's famous list”, Equal Times, 20 July 2017. equaltimes.org/whose-world-heritage-the-problem?lang=en\#.WyRBTlOFPMI (accessed June 24, 2018).

5. Ibid.

6. Western Sahara is considered the last colony in Africa. Formerly colonised by Spain and currently under Moroccan rule, half of its population have been living as refugees in neighbouring Algeria since 1975, waiting for the opportunity to return home and have their own independent state. For more in-depth information about the Saharawi conflict, see BOUKHARS Anouar and ROUSSELIER Jacques, Perspectives on Western Sahara: Myths, Nationalisms, and Geopolitics, Lanham, Rowman \& Littlefield, 2014.

7. STOKES Martin, Ethnicity, Identity and Music: The Musical Construction of Place, Oxford, Berg, 1994.

8. Encompassing Western Sahara, Mauritania, and parts of Morocco, Algeria and Mali, the Trab ElBidhân is the most western region of the Sahara desert. It was first inhabited by the Bidhân, a stratified society born out of the mixture of Saharan Berbers, Arabs and sub-Saharan black populations. The Bidhân were nomads dedicated to pastoralism and trade who spoke a common language, Hassâniya, and shared similar oral traditions, spiritual life, material culture, and artistic forms.

9. GAOR, $19^{\text {th }}$ Session, Annex No. 8 (part I), UN Document A/5800/Rev.1, 1964, p. 290-91.

10. Mauritania withdrew its claim over Western Sahara in 1979, recognising the SADR.

11. eacnur.org/blog/refugiados-saharauis-40-anos-de-vida-en-los-campos/(accessed May 19, 2019).

12. The Boujdour camp first started as a women's educational centre, only becoming a residential camp in 2012.

13. Hard rock desert terrain in the southwest of Algeria.

14. zUNES Stephen and MUNDY Jacob, Western Sahara: War, Nationalism and Conflict Irresolution, New York, Syracuse University Press, 2010.

15. COUNSEL Graeme, Mande Popular Music and Cultural Policies in West Africa: Griots and Government Policy since Independence, Saabrucken, VDM Verlag, 2009.

16. The only non-nationalist music that was still performed on a regular basis in the camps during the war was the spiritual medeh (praise) in honour of Prophet Mohammed, due to the need of the refugees to seek not only for physical refuge but also for spiritual one. For more information on Bidhân traditional music and poetic themes, see GUIGNARD Michel, Musique, honneur et plaisir au Sahara: étude psycho-sociologique et musicologique de la société maure, Paris, Librairie Orientaliste Paul Geuthner, 2005; and DEUBEL Tara, "Poetics of Diaspora: Sahrawi Poets and Postcolonial Transformations of a Trans-Saharan Genre in Northwest Africa", The Journal of North African Studies, vol. 17, no.2, 2012, p. 295-314.

17. "Pues que como estamos tan volcados en solucionar nuestra situación política y cantamos sobre todo canciones de denuncia y resistencia, suele pasar que las canciones más tradicionales se quedan a un lado". LASUEN Ainhoa, "Mariem Hassan. "Nunca hubiera pensado que la música saharaui llegara tan alto"', El Correo, $3^{\text {rd }}$ January 2013. elcorreo.com/vizcaya/v/20130103/guipuzcoa/mariem-hassannunca-hubiese-20130103.html (accessed May 19, 2019). 
18. воUM Aomar. "Dancing for the Moroccan State: Ethnic Folk Dances and the Production of National Hybridity”, BOUDRAA Nabil and KRAUSE Josephy, North African Mosaic: A Cultural Reappraisal of Ethnic and Religious Minorities, Newcastle, Cambridge Scholars Publishing, 2007, p. 214-237.

19. sahara-culture.com/Default.aspx?tabid=408 (accessed June 24, 2018).

20. taragalte.org/?lang=en (accessed June 24, 2018).

21. unesco.org/culture/intangible-heritage/26arb_uk.htm (accessed June 24, 2018).

22. DeUbel Tara Flynn, Between Homeland and Exile: Poetry, Memory, and Identity in Sahrawi Communities, PhD thesis, USA, University of Arizona, School of Anthropology, 2010.

23. This cultural war and its many manifestations are thoroughly represented in the 2014 documentary film Life is Waiting: Referendum and Resistance in Western Sahara, directed by international activist Iara Lee (Caipirinha Productions).

24. Originally launched in Spanish: Observatorio Internacional para la Protección del Patrimonio Cultural en el Sáhara Occidental (RASD, Ministry of Culture, Constitución del Observatorio Internacional para la Protección del Patrimonio Cultural en el Sáhara Occidental [info leaflet], 2008).

25. ROBles Juan, MAHMUd AWAH Bahia, GIMENo Juan Carlos, Legna, Habla el verso saharaui, 2014. youtube.com/watch?v=aoU6ehmm5KM (accessed May 19, 2019).

26. ANDRÉS OLIVEIRA Julia, MOHAMED BABA Ahmed Salem ould, CONTRERAS RODRíGUEZ Eduardo, DOMínguEZ Manuel, PÉREZ RIVERA Lola, Haul. Música saharaui, Turpin Editores, 2016.

27. sandblast-arts.org/studio-live.html (accessed May 19, 2019).

28. sounds.bl.uk/World-and-traditional-music/Violeta-Ruano-portraits-of-SaharawiMusic (accessed May 19, 2019).

29. HANDLER Richard, Nationalism and the Politics of Culture in Quebec, Madison, University of Wisconsin Press, 1988.

30. ASKEW Kelly, Performing the Nation: Swahili Music and Cultural Politics in Tanzania, Chicago, University of Chicago Press, 2002.

31. blogs.bl.uk/music/2014/05/saharawi-music-in-the-refugee-camps-in-swalgeria.html (accessed November 25, 2018).

32. RUANO POSADA Violeta, "Performing the Cause: The Politics of Musical Expression in the Saharawi Refugee Camps", Boulay Sebastién and FREIRE Francisco, Culture and Politics in the West Sahara (Mauritania, Mali, Western Sahara): Arts, Activism and the State in a Conflict Area, France, L'Étrave, 2017, p. 101-126.

33. FELD Steven, "From Schizophonia to Schismogenesis: On the Discourses and Commodification Practices of 'World Music' and 'World Beat', KEY Charles and FELD Steven, Music Grooves: Essays and Dialogues, Chicago, University of Chicago Press, 1994, p. 285.

34. DAVIES Charlotte Aull, Reflexive Ethnography: A Guide to Researching Selves and Others, London and New York, Routledge, 2008, p. 4. For a more in-depth reflection on my role on this project, see RUANO POSADA Violeta, "Portraits of Saharawi Music: When Cultural Preservation Meets Political Activism", African Music, Journal of the International Library of African Music, vol. 10, no. 2, 2016, p. 108-125.

35. LIPSITZ George, Dangerous Crossroads: Popular Music, Postmodernism and the Poetics of Place, London, Verso, 1997, p. 137.

36. For a more in-depth discussion on the different ways Saharawi musicians are expressing their identity outside the realm of the Saharawi Ministry of Culture, see RUANO POSADA, "Performing the Cause".

37. BÁrbulo Tomás, La Historia Prohibida del Sáhara Español. Las Claves del Conflicto que Condiciona las Relaciones entre España y el Magreb, $2^{\text {nd }}$ ed, Madrid, Destino, 2010.

38. GUIGNARD, Musique, Honneur et Plaisir au Sahara, p. 102. 
39. DU PUigaudeau Odette et SÉnONes Marion, Mémoire du Pays Maure: 1934-1960, Paris, Ibis, 2000, p. 109.

40. sounds.bl.uk/World-and-traditional-music/Violeta-Ruano-portraits-of-SaharawiMusic (accessed November 25, 2018).

41. youtube.com/watch?v=VOr4tx0yrLE (from minute 11:20 onwards; accessed November 25, 2018).

42. discogs.com/Various-West-Africa-At-The-British-Library/release/10651781 (accessed November 25, 2018).

43. Regarding the third objective, finding out the meaning of Saharawi music for the local population, Portraits of Saharawi Music laid the foundation for my doctoral research, which has been published so far in a series of articles and book chapters that, in turn, have kept promoting Saharawi music and culture in different academic circles. See RUANO POSADA Violeta and SOLANA MORENo Vivian, "The Strategy of Style: Music, Struggle, and the Aesthetics of Saharawi Nationalism in Exile", Transmodernity: Journal of Peripheral Cultural Production of the Luso-Hispanic World, 2015; RUANO POSADA Violeta, "Shaheed El Uali and Beyond: 40 Years of Resistance Music in Western Sahara”, Bring the Noise: Ethnomusicology Review, 26 February 2016; RUANO POSADA, "Portraits of Saharawi Music: When Cultural Preservation Meets Political Activism"; RUANO POSADA, "Performing the cause"; RUANO POSADA Violeta, "La musique nidal sahraouie et la lutte en partage", BOULAY Sebastién and CORREALE Francesco, Sahara occidental: conflit oublié, population en mouvement, Tours, Presses Universitaires François Rabelais, 2018; and RUANO POSADA Violeta, "Telling (Hi)Stories through Music: The Power of Performance in the Saharawi Struggle", CARL Florian, FUHR Michael, OTCHERE Eric D. and VOGELS Raimund, Memory, Power, and Knowledge in African Music and Beyond, Germany, Olms-Verlag, University of Hildesheim Press, forthcoming (2019).

44. securitycouncilreport.org/un-documents/?c=western-sahara/ (accessed November 25, 2018).

45. LIPSITZ, Dangerous Crossroads, p. 137.

46. CARO BAROJA Julio, Estudios Sahararianos, Madrid, Calamar, 2008, p. 258.

47. GIMÉNEZ AMORÓs Luis, Haul Music: Transnationalism and Musical Performance in the Saharaui Refugee Camps of Tindouf, Algeria, MMus dissertation, Grahamstown, Rhodes University, 2012, p. 39-40.

48. Named after the National Holiday on February $27^{\text {th }}$ (the anniversary of the proclamation of the Saharawi republic).

49. ASKEW, Performing the Nation, p. 140-141.

50. GRANT, "Rethinking Safeguarding", p. 35.

51. Ibid.

\section{ABSTRACTS}

The preservation of cultural practices within the framework of the UNESCO ICH lists has been tied to the protection of cultural diversity, intercultural dialogue and community identity. Moreover, it is inextricably linked to questions of national identity, especially given that submissions are made on an (internationally recognised) nation-state basis. This becomes problematic in the case of long-standing unrecognised states, such as the Saharawi Arab Democratic Republic (SADR). The protracted refugee status of the Saharawi people-based in refugee camps in the south-western Algerian desert since Morocco occupied their homeland 
Western Sahara in 1975-is a major obstacle in their struggle for independence. Their recent history of war, occupation, exile and cultural appropriation has threatened the survival of Saharawi musical and poetic practices, as well as restricting their access to international bodies that could provide cultural safeguarding assistance.

To address this situation, the Saharawi cultural authorities have collaborated with international organisations (e.g. the Autonomous University of Madrid and the British Library) to create archives of Saharawi poetry and music. In addition, every year they organise large festivals to showcase traditional culture, featuring musical competitions especially aimed at youth. To prepare for these competitions, young people-who have gradually become less aware of the Saharawi Bedouin way of life before exile-are assisted by national musicians and encouraged to research their own traditional music by establishing dialogues with the elders. So far, these measures have had significant short-term impact on the local population, engaging the youth in anecdotal research on their traditional culture; however, due to the Saharawi government's chronic lack of resources, it has been impossible both to sustain such measures in the long term and to achieve international recognition.

Focusing on two case studies-1) the British Library preservation project "Portraits of Saharawi Music" and 2) a music competition during the Saharawi national celebrations in February 2014this article explores the efforts of the SADR to safeguard their musical heritage using a mix of material (recorded archives) and non-material (oral transmission) strategies. It also analyses the ways in which socio-political interests such as the reinforcement of a self-built national identity have encouraged the need to keep particular styles (e.g. traditional/national music) alive under the label of intangible heritage preservation.

La préservation de pratiques culturelles dans le cadre des listes du Patrimoine Culturel Immatériel (PCI) de l'UNESCO est liée à la protection de la diversité culturelle, du dialogue interculturel et de l'identité des communautés. En outre, elle est inextricablement liée aux questions de culture nationale, étant donné que les candidatures sont soumises au niveau des États-nation (ceux qui sont reconnus internationalement). Cela devient problématique dans le cas des États non reconnus depuis longtemps, tels que la République arabe sahraouie démocratique (RASD). Le statut prolongé de réfugié du peuple sahraoui - basé dans des camps de réfugiés dans le désert du sud-ouest algérien depuis l'occupation par le Maroc de leur territoire du Sahara occidental en 1975 - constitue un obstacle majeur dans la lutte pour l'indépendance. Leur histoire récente faite de guerre, d'occupation, d'exil et d'appropriation culturelle menace la survie des pratiques musicales et poétiques sahraouies, tout en limitant leur accès aux organismes internationaux susceptibles de soutenir la sauvegarde de leur culture.

Pour remédier à cette situation, les autorités culturelles sahraouies ont collaboré avec des organisations internationales (par exemple l'Université autonome de Madrid et la British Library) afin de créer des archives de poésie et de musique sahraouies. Chaque année, elles organisent d'importants festivals afin de valoriser la culture traditionnelle, avec des concours de musique destinés en particulier à la jeunesse. Pour se préparer à ces compétitions, les jeunes qui se sont peu à peu éloignés du mode de vie des bédouins sahraouis d'avant l'exil - sont aidés par des musiciens nationaux et encouragés à faire des recherches sur leur propre musique traditionnelle en établissant un dialogue avec les aînés. Jusqu'à présent, ces mesures ont eu, à court terme, un impact significatif sur la population locale, en engageant les jeunes à recueillir des témoignages sur leur culture traditionnelle. Cependant, le manque chronique de ressources du gouvernement sahraoui a rendu impossible à la fois le maintien de ces mesures sur le long terme, et l'obtention d'une reconnaissance internationale.

Cet article se concentre sur deux études de cas : 1) le projet de sauvegarde "Portraits de la musique sahraouie " de la British Library et 2) un concours de musique organisé lors des célébrations nationales sahraouies en février 2014. Il revient sur les efforts engagés par la RASD 
pour sauvegarder son patrimoine musical, fondés sur un mélange de ressources matérielles (archives enregistrées) et non matérielles (transmission orale). Il analyse également la manière dont des intérêts sociopolitiques, tels que le renforcement d'une culture nationale autoconstruite, ont encouragé la préservation de styles particuliers (par exemple, la musique traditionnelle / nationale) au titre de la sauvegarde du patrimoine immatériel.

\section{INDEX}

Mots-clés: sauvegarde, archive, patrimoine musical menacé, Sahara occidental, musique sahraouie

Keywords: preservation, archive, endangered musical heritage, Western Sahara, Saharawi music

\section{AUTHOR}

\section{VIOLETA RUANO POSADA}

Dr Violeta Ruano Posada is a musician and researcher specialised in the music of the Bidhân region in north-west Africa (mainly Mauritania and Western Sahara). During her PhD studies in Music Research at the School of Oriental and African Studies (SOAS, University of London), she explored the relationship between music, resistance and exile within Saharawi culture, spending over a year living and researching in the Saharawi refugee camps (southwest Algeria), Mauritania and Spain. She is currently the leader of a music education project being developed in the Saharawi refugee camps in collaboration with several UK organisations. 